\title{
Preterm birth and periodontitis: a dilemma of current obstetrics
}

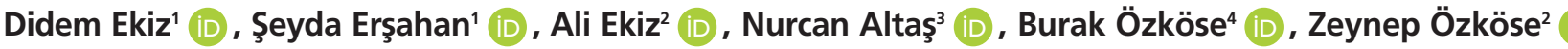 \\ ${ }^{1}$ Department of Endodontics, Faculty of Dentistry, Istanbul Medipol University, Istanbul, Turkey \\ ${ }^{2}$ Maternal-Fetal Medicine Unit, Clinics of Obstetrics and Gynecology, Kanuni Sultan Suleyman Training and Research Hospital, Istanbul, Turkey \\ ${ }^{3}$ Faculty of Dentistry, Istanbul Medipol University, Istanbul, Turkey \\ ${ }^{4}$ Clinics of Obstetrics and Gynecology, Kanuni Sultan Suleyman Training and Research Hospital, Istanbul, Turkey
}

\begin{abstract}
Objective: In current obstetric literature, the influence of periodontal disease on adverse perinatal outcome is a matter of debate. In this prospective cohort study, we aimed to investigate whether there is an association between periodontal status and preterm birth (PTB) via previously unused methodology.

Methods: In this prospective cohort study, we examined the periodontal status of mothers within 24 hours following birth. In total, 226 puerperal women were examined and placed in two groups; a PTB group consisting of 71 patients, and a term birth (TB) group consisting of 155 patients. All risk factors known to be etiologic factors for PTB were excluded. The patients were classified into three main groups in both groups based on oral examination findings: gingivitis $(\mathrm{G})$, periodontitis $(\mathrm{P})$, and healthy $(\mathrm{H})$.

Results: Both groups were identical in terms of demographic factors. Regarding possibly influencing factors including smoking, passive smoking and tooth brushing habits, both groups were also identical. The distribution of $\mathrm{G}, \mathrm{P}$ and $\mathrm{H}$ among the groups were similar and the difference was not significant $(\mathrm{p}=1)$. $\mathrm{p}$-values among the PTB and TB groups were $40.8 \%$ and $40.6 \%$, respectively, and the difference was not significant. When collected data were reanalyzed by splitting the PTB group into early and late PTB, the results were similar and the difference was not significant.

Conclusion: The confusion over this conflicting association likely results from confounding factors, other factors that can cause PTB and lack of consensus over the diagnostic criteria for periodontal disease. Finally, our prospective cohort study, which strictly excluded possible confounding variables, has not confirmed any association between periodontitis and preterm birth.
\end{abstract}

Keywords: Preterm birth, periodontitis, gingivitis, adverse pregnancy outcome, risk factor.
Özet: Preterm doğum ve periodontit: Mevcut doğum biliminde bir ikilem

Amaç: Mevcut doğum literatüründe, periodontal hastalığın advers perinatal sonuç üzerindeki etkisi tartışmalıdır. Bu prospektif kohort çalışmasında, periodontal durum ile preterm doğum (PD) arasında bir ilişki olup olmadığını daha önce kullanılmamış bir metodolojiyle araştırmayı amaçladık.

Yöntem: Bu prospektif kohort çalışmasında, doğumdan sonraki 24 saat içinde kadınların periodontal durumunu inceledik. Puerperal dönemde olan toplam 226 kadın incelendi ve iki gruba ayrıldı; PD grubunda 71 , miadında doğum (MD) grubunda ise 155 hasta yer almaktaydı. PD için etiyolojik faktör olduğu bilinen tüm risk faktörleri çalışma dışı bırakıldı. Hastalar, her iki grupta oral muayene bulguları temel alınarak üç ana gruba ayrıldı: Gingivit $(\mathrm{G})$, periodontit $(\mathrm{P})$ ve sağlıklı (S).

Bulgular: Her iki grup da demografik faktörler açısından aynıydı. Olasılıkla etkisi olan sigara kullanımı, pasif içicilik ve diş firçalama alışkanlığı gibi faktörler de her iki grupta aynı idi. Gruplar arasındaki $G, P$ ve $S$ dağılımı benzerdi ve aradaki fark anlamlı değildi $(\mathrm{p}=1)$. PD ve $\mathrm{MD}$ grupları arasındaki $\mathrm{p}$ değerleri sırasıyla $\% 40.8$ ve $\% 40.6$ idi ve fark anlamlı değildi. Toplanan veriler PD grubunu erken ve geç PD şeklinde ikiye ayırarak yeniden analiz edildiğinde, elde edilen sonuçlar benzerdi ve fark anlamlı değildi.

Sonuç: Bu çelişkili ilişkiye yönelik kafa karışıklığının, PD’ye neden olabilecek ve periodontal hastalığa yönelik tanı kriterleri üzerinde fikir birliği olmayan çelişkili diğer faktörlerden kaynaklanması muhtemeldir. Son olarak, muhtemelen çelişkili değişkenleri kesin şekilde çalışma dışı tutan prospektif kohort çalışmamız, periodontit ve preterm doğum arasında herhangi bir ilişkiyi doğrulamamaktadır.

Anahtar sözcükler: Preterm doğum, periodontit, gingivit, advers doğum sonucu, risk faktörü.

Correspondence: Şeyda Erşahan, MD. Department of Endodontics, Faculty of Dentistry, Istanbul Medipol University, Istanbul, Turkey. e-mail: seydaersahan@hotmail.com / Received: December 10, 2019; Accepted: April 8, 2020

Please cite this article as: Ekiz D, Erşahan Ş, Ekiz A, Altaş N, Özköse B, Özköse Z. Preterm birth and periodontitis: a dilemma of current obstetrics. Perinatal Journal 2020;28(1):36-41. doi:10.2399/prn.20.0281008 


\section{Introduction}

Preterm birth (PTB), which refers to a delivery before 37 weeks of gestation, is still a major cause of perinatal morbidity and mortality. Despite advances in technology and increasing antenatal surveillance quality, the incidence of preterm birth exhibits a regular rising trend in both developing and developed countries. The preterm infants are at elevated risk for death, neurodevelopmental disabilities, cognitive impairment, and behavioral disorders. ${ }^{[1]}$ PTB is a major public health problem. Since a considerable amount of singleton pregnancies, approximately $11 \%$, give birth before 37 weeks of gestation, the etiology of preterm birth takes more attention gradually. ${ }^{[2]}$

Although a number of causes have been identified for PTB, approximately $70 \%$ of cases of PTB are spontaneous, meaning no specific cause can be identified. ${ }^{[3]}$ Infection and/or inflammation can play a role as a causative factor in PTB pathogenesis. Previous studies have reported an association between infection and/or inflammation and preterm birth. ${ }^{[3-6]}$ Periodontal disease, an inflammatory disease that destroys tooth-supporting connective tissue and bone, has been accused of causing adverse perinatal outcomes. According to current literature, although many studies - even metaanalyses- have been published in this field, results are still conflicting. Some authors have demonstrated a positive association between periodontal disease and PTB,${ }^{[7-12]}$ whereas others have failed to demonstrate an

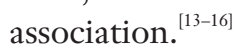

Therefore, we aimed to examine the periodontal status of mothers both who gave birth preterm without any reasons known to be etiologic factors for $\mathrm{PTB}$, and those who gave full-term birth (TB).

\section{Methods}

This prospective cohort study was conducted on maternity patients at the obstetrics department of Kanuni Sultan Suleyman Training and Research Hospital between December 2015 and June 2016. The study was conducted with ethical approval from the hospital's Ethics Committee dated June 16, 2015 and the study number of 10902 . Patients who were in the postpartum period within 24 hours after birth were recruited from the postpartum unit. Patients were allocated to two groups: The first group was constituted of preterm deliveries and named the preterm group, and the second group was constituted of term deliveries and named term group. Preterm delivery was defined as delivery before the completion of 37 weeks of gestation.

The primary outcome measure was the presence of periodontitis. The prevalence of periodontitis was reported between $10 \%$ and $60 \% \cdot{ }^{[17,18]} \mathrm{We}$ expected the rate of periodontitis in preterm deliveries $40 \% .^{[19]}$ Thus, an enrollment of at least 146 patients was required such that the study would have a power $\% 80$ to detect the difference with 0.05 type 1 error. Required sample size was estimated using MedCalc (version 13.3; MedCalc Software, Mariakerke, Belgium) statistical software.

Inclusion criteria for the preterm group were spontaneous delivery between 24 and 37 gestational weeks without any known risk factors for $\mathrm{PB}$, and the presence of at least 20 teeth on oral examination. Inclusion criteria for the term group were spontaneous delivery between 37 and 41 gestational weeks and the presence of at least 20 teeth on oral examination. The following findings constituted exclusion criteria for enrollment in the study: (1) patients who had any risk factors for preterm delivery, such as a short cervix, previous preterm delivery, adolescent pregnancy, premature rupture of membrane, multiple gestations or congenital uterine abnormality; (2) patients who had medical problems or infections during pregnancy (like urinary infections); (3) presence of fetal structural anomaly; (4) medically indicated preterm deliveries; (5) patients who had labor induction.

Patients were consecutively enrolled in the study between the dates mentioned above and informed consent was obtained from all participants. Before examination, patients were questioned on whether they are smokers and whether they have tooth brushing habits. Oral evaluation was performed within 24 hours after delivery. The periodontal status of patients was evaluated in terms of the number of teeth and clinical periodontal parameters. According to the physical examination results, plaque index (PI), gingival index (GI) and probing pocket depth (PPD) were detected quantitatively. All examinations were performed by the same researcher at six points of each tooth (mesiobuccal, midbuccal, distobuccal, mesiolingual, midlingual, 
and distolingual) by using Williams' marked probe. The patients were classified into three main groups in both groups based on oral examination findings: First, the gingivitis group $(G)$ (who had no periodontal pockets, but had bleeding on more than $10 \%$ of gum surfaces after light mechanical stimulation); second, the periodontitis group $(\mathrm{P})$ (who had $4 \mathrm{~mm}$ pocket depth on two or more surfaces); and third, the healthy group (H) (who did not meet G or P criteria or were completely orally healthy). ${ }^{[20]}$

A total of 226 puerperal women who met all inclusion criteria were enrolled the study. Seventy-one of them constituted the preterm group and the remaining 155 constituted the term group. The statistical analysis was carried out with MedCalc statistical software. Data are presented as means $\pm \mathrm{SD}$ (standard deviation). The Kolmogorov-Smirnov test assessed the normality of the distribution of continuous variables. A Chi-squared test and Fisher's exact test were used to analyze categorical variables, and Student's t-test was used for the analysis of normally distributed continuous variables. MannWhitney U-test was used for non-normally distributed variables. A p-value $<0.05$ was deemed statistically significant.

\section{Results}

During the research period, 226 puerperal women's results were analyzed after inappropriate oral examinations were excluded. Thus, 71 cases of PTB and 155 cases of TB were evaluated. The demographic characteristics, oral examination results, and final diagnosis of the cases are shown in Table 1. There were no statistically significant differences between the two groups in terms of age, gravidity and parity. As expected, the mean gestational age at delivery and weight of newborns at delivery were significantly higher in the term group.

Both groups contained similar ratios of smoking, passive smoking and tooth brushing. Thus, the groups were also identical in terms of these influencing factors. When the groups were compared with respect to PI, GI and PPD, no statistically significant difference was observed. The distributions of PI, GI and PPD that constitute diagnostic criteria of periodontitis are shown in box plot graph format (Fig. 1).

According to the oral examination results, 38\% of the patients classified as healthy were in the preterm group and $38.7 \%$ in the term group; this difference is

Table 1. The demographic characteristics, oral examination results and final diagnosis of the cases.

\begin{tabular}{|c|c|c|c|}
\hline & $\begin{array}{l}\text { Preterm group }(n=71) \\
\text { Mean } \pm \text { SD/range }\end{array}$ & $\begin{array}{l}\text { Term group }(n=155) \\
\text { Mean } \pm \text { SD/range }\end{array}$ & p-value \\
\hline Age* $^{*}$ & $27.97 \pm 5.46$ & $27.43 \pm 4.42$ & 0.467 \\
\hline $\mathrm{BMI}^{*}$ & $27.34 \pm 5.13$ & $28.01 \pm 3.77$ & 0.324 \\
\hline $\mathrm{G}^{+}$ & $2(1-9)$ & $2(1-6)$ & 0.464 \\
\hline $\mathrm{P}^{\dagger}$ & $2(1-9)$ & $2(1-5)$ & 0.135 \\
\hline $\mathrm{A}^{\dagger}$ & $0(0-3)$ & $0(0-3)$ & 0.457 \\
\hline $\mathrm{GA}$ at delivery ${ }^{\dagger}$ & $35.86(3.57)$ & $39(1.29)$ & $<0.0001$ \\
\hline Newborn weight ${ }^{\dagger}$ & $2540 \pm 650$ & $3350 \pm 520$ & $<0.0001$ \\
\hline $\mathrm{PI}($ mean)* & $1.50 \pm 0.92$ & $1.57 \pm 0.90$ & 0.587 \\
\hline Gl (mean)* & $0.96 \pm 0.76$ & $0.95 \pm 0.78$ & 0.929 \\
\hline \multirow[t]{2}{*}{$\mathrm{PPD}(\text { mean })^{\dagger}$} & $2.42 \pm 0.39$ & $2.5 \pm 0.55$ & 0.534 \\
\hline & n (\%) & $n(\%)$ & p-value \\
\hline $\mathrm{CS}, \mathrm{n}(\%)^{\ddagger}$ & 37 (52.1) & $75(48.4)$ & 0.668 \\
\hline Smoking ${ }^{\ddagger}$ & $11(15.5)$ & $24(15.5)$ & 1.000 \\
\hline Passive smoking ${ }^{\ddagger}$ & $40(56.3)$ & $75(48.4)$ & 0.316 \\
\hline Tooth brush ${ }^{\ddagger}$ & 39 (54.9) & $71(45.8)$ & 0.251 \\
\hline Healthy ${ }^{\ddagger}$ & $27(38)$ & $60(38.7)$ & 1.000 \\
\hline Gingivitis ${ }^{\ddagger}$ & $15(21.1)$ & $32(20.6)$ & 1.000 \\
\hline Periodontitis ${ }^{\ddagger}$ & $29(40.8)$ & $63(40.6)$ & 1.000 \\
\hline
\end{tabular}

*Student's t-test; ${ }^{\dagger}$ Mann-Whitney U test; ${ }^{\ddagger}$ Chi-square test. A: abortion; CS: cesarean section; G: gravida; GA: gestational age; GI: gingival index; P: parity; PI: plaque index; PPD: probing pocket depth. 


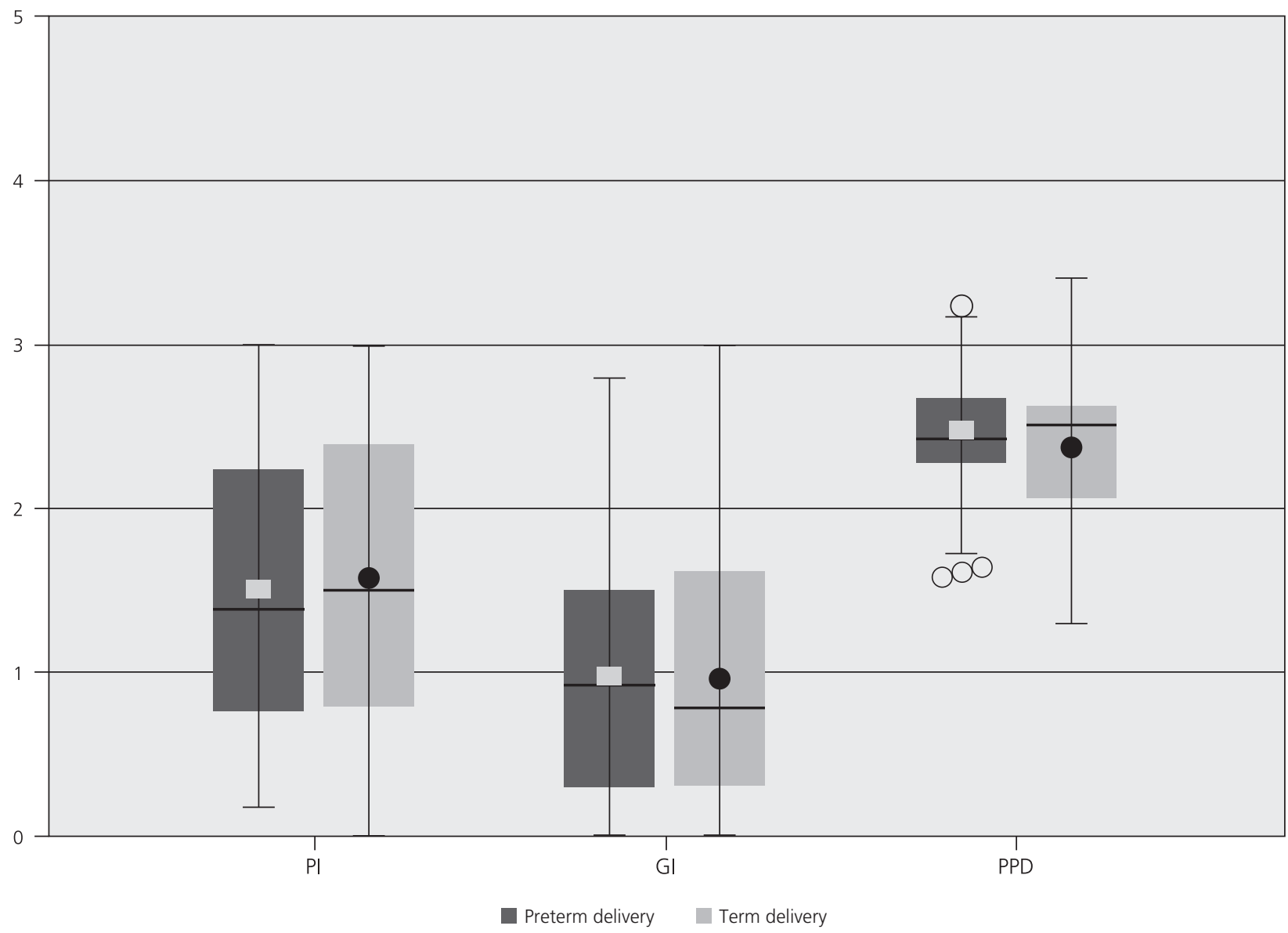

Fig. 1. The distributions of PI, GI and PPD that constitute diagnostic criteria of periodontitis. GI: gingival index; PI: plaque index; PPD: probing pocket depth.

not statistically significant. Finally, both periodontitis and gingivitis ratios were similar in both groups.

The collected data were reanalyzed by splitting the preterm group into early and late preterm. Early preterm group was defined as deliveries before completing 34 gestational weeks $(\mathrm{GW})$ and late preterm group was defined as deliveries between 34 and 37 GW. The early preterm group group included 20 patients and mean gestational age at delivery and standard deviations were 30.21 weeks and 2.59 respectively. The late preterm group consisted of 51 patients and mean gestational age at delivery and standard deviations were 36.02 weeks and 0.83 respectively. Finally, the periodontitis rates were the same for all three groups. In other words, the results were uniform.
Since the aim of this study was to analyze the association between periodontitis and $\mathrm{PB}$, we have not analyzed the association between presence of periodontitis and birth weight. The distribution of diagnoses according to both groups are presented in Table 2 .

\section{Discussion}

Maternal periodontitis has been linked to an increased risk for adverse perinatal outcomes including preterm birth, preeclampsia, fetal growth restriction, or perinatal death. Although the associations between periodontitis and adverse perinatal outcomes are still questionable, some mechanisms have been put forward, such as increasing inflammatory mediators in plasma or exposure to systemic bacterial products from chronic infec- 
Table 2. Reanalyzed results according to early and late preterm birth.

\begin{tabular}{|c|c|c|c|c|}
\hline & $\begin{array}{l}\text { Early preterm group } \\
\qquad \begin{array}{c}(m e a n \pm S D) \\
(n=20)\end{array}\end{array}$ & $\begin{array}{l}\text { Late preterm group } \\
\qquad \begin{array}{c}(\text { mean } \pm \text { SD }) \\
(n=51)\end{array}\end{array}$ & $\begin{array}{c}\text { Term group } \\
(m e a n \pm S D) \\
(n=155)\end{array}$ & p-value \\
\hline$\left.\mathrm{P}\right|^{*}$ & $1.66 \pm 1.01$ & $1.44 \pm 0.88$ & $1.57 \pm 0.90$ & 0.626 \\
\hline$\left.G\right|^{*}$ & $1.08 \pm 0.85$ & $0.92 \pm 0.73$ & $0.95 \pm 0.78$ & 0.772 \\
\hline $\mathrm{PPD}^{+}$ & $2.36 \pm 0.6$ & $2.5 \pm 0.4$ & $2.5 \pm 0.6$ & 0.691 \\
\hline Healthy ${ }^{\ddagger}(n, \%)$ & 7 (35) & $20(39.2)$ & $60(38.7)$ & 0.943 \\
\hline Gingivitis₹ $(n, \%)$ & $4(20)$ & $11(21.6)$ & $32(20.6)$ & 0.986 \\
\hline Periodontitis ${ }^{\ddagger}(n, \%)$ & $9(45)$ & $20(39.2)$ & $63(40.6)$ & 0.905 \\
\hline
\end{tabular}

${ }^{\star}$ Kruskal-Wallis test; ${ }^{\dagger}$ Median interquartile range; ${ }^{\ddagger}$ Chi-square test. GI: gingival index; PI: plaque index; PPD: probing pocket depth.

tion. ${ }^{[16]}$ As a result, many studies have been published regarding these associations. Conflicting results may arise from varying definition of periodontitis and other factors that can cause PTB.

In our prospective cohort study, 226 puerperal women`s periodontal status was examined within 24 hours after giving birth. In our study, we defined periodontitis as patients whose oral examinations had $4 \mathrm{~mm}$ or more pocket depth on two or more dental surfaces. Our groups were identical in terms of demographical factors. Our study results failed to demonstrate an association, and the results are in line with a large prospective study which was published by Srinivas et al. ${ }^{[15]}$ This study was a multicenter prospective study and a large number of patients were included, but Srinivas et al. ${ }^{[15]}$ used a periodontal attachment loss $3 \mathrm{~mm}$ on three or more teeth as criteria for periodontitis diagnosis, which is slightly different from our criteria. Likewise, a recent study by Fogacci et al. ${ }^{[17]}$ reported that maternal periodontal disease is not a risk factor associated with preterm infants' low birth weights. Similar results are reported in studies conducted in different ethnic groups such as the Spanish population, ${ }^{[16]}$ and they also used 3 $\mathrm{mm}$ for diagnosis. However, one recent study found little correlation with serum levels of pro-inflammatory proteins in women with PTB and low birth weight. ${ }^{[18]}$

Some meta-analyses, for example Corbella et al.'s study, ${ }^{[19]}$ make abstainer comments over this association because of important confounding variables. In a systematic review by Xiong et al., ${ }^{[20]}$ researchers reviewed 25 studies and speculated that periodontal disease may be associated with an increased risk of adverse pregnancy outcomes, but they underlined that more methodologi- cally rigorous studies are needed in this field. Besides, a number of important studies ${ }^{[2]]}$ and meta-analyses ${ }^{[2,23]}$ reported that treatment of periodontitis during pregnancy does not reduce spontaneous preterm birth. These results make the already-debated association more questionable.

One of the unique features of the present study is its methodology. According to our knowledge, there is not any study in the current literature which prospectively examines patients in the early postpartum period. On the other hand, a limited number of early preterm birth cases was a weakness of sub-group analysis.

In the present study, 1999 classification of periodontal disease was used. ${ }^{[2]}$ In 2018, the classification of periodontal diseases was renewed. The new classification ${ }^{[25]}$ addressed unresolved issues with the previous classification $^{[24]}$ by identifying three different forms of periodontitis based on current knowledge on the diseases' pathophysiology: (a) necrotizing periodontitis, (b) periodontitis as a manifestation of systemic disease and (c) periodontitis, whereas the last form includes the previously recognized subtypes of "chronic" and "aggressive" periodontitis. ${ }^{[25]}$ Therefore, further studies evaluating PTB in relation to the new classification are needed.

\section{Conclusion}

In conclusion, according to our results, we have not detected any associations between spontaneous PTB and periodontitis. Nevertheless, future large scale randomized controlled trials are needed to clarify the controversial association.

Conflicts of Interest: No conflicts declared. 


\section{References}

1. Bhutta AT, Cleves MA, Casey PH, Cradock MM, Anand KJ. Cognitive and behavioral outcomes of school-aged children who were born preterm: a meta-analysis. JAMA 2002;288: 728-37.

2. Martin JA, Hamilton BE, Sutton PD, Ventura SJ, Menacker F, Munson ML. Births: final data for 2003. Natl Vital Stat Rep 2005;54:1-116.

3. Goldenberg RL, Culhane JF, Iams JD, Romero R. Epidemiology and causes of preterm birth. Lancet 2008;371:75-84.

4. Gibbs RS, Romero R, Hillier SL, Eschenbach DA, Sweet RL. A review of premature birth and subclinical infection. Am J Obstet Gynecol 1992;166:1515-28.

5. Gibbs RS. The relationship between infections and adverse pregnancy outcomes: an overview. Ann Periodontol 2001;6: 153-63.

6. Tütüncü L, Ardıç N, Müngen E, Ergür AR, Yergök YZ. Urinary tract infection in pregnancy. Perinatal Journal 2005;13: 114-21.

7. Xiong X, Buekens P, Vastardis S, Yu SM. Periodontal disease and pregnancy outcomes: state-of-the-science. Obstet Gynecol Survey 2007;62:605-15.

8. Goepfert AR, Jeffcoat MK, Andrews WW, Faye-Petersen O, Cliver SP, Goldenberg RL, et al. Periodontal disease and upper genital tract inflammation in early spontaneous preterm birth. Obstet Gynecol 2004;104:777-83.

9. Radnai M, Gorzo I, Nagy E, Urban E, Novak T, Pal A. A possible association between preterm birth and early periodontitis. A pilot study. J Clin Periodontol 2004;31:736-41.

10. Boggess KA, Lieff S, Murtha AP, Moss K, BeckJ, Offenbacher S. Maternal periodontal disease is associated with an increased risk for preeclampsia. Obstet Gynecol 2003;101:227-31.

11. Jeffcoat MK, Geurs NC, Reddy MS, Cliver SP, Goldenberg RL, Hauth JC. Periodontal infection and preterm birth: results of a prospective study. J Am Dent Assoc 2001;132:87580.

12. Vergnes JN, Sixou M. Preterm low birth weight and maternal periodontal status: a meta-analysis. Am J Obstet Gynecol 2007; 196:135.e1-7.

13. Skuldbol T, Johansen KH, Dahlen G, Stoltze K, Holmstrup $\mathrm{P}$. Is pre-term labour associated with periodontitis in a Danish maternity ward? J Clin Periodontol 2006;33:177-83.

14. Moore S, Ide M, Coward PY, Randhawa M, Borkowska E, Baylis R, et al. A prospective study to investigate the relation- ship between periodontal disease and adverse pregnancy outcome. Br Dent J 2004;197:251-8.

15. Srinivas SK, Sammel MD, Stamilio DM, Clothier B, Jeffcoat MK, Parry S, et al. Periodontal disease and adverse pregnancy outcomes: is there an association? Am J Obstet Gynecol 2009; 200:497.e1-8.

16. Santa Cruz I, Herrera D, Martin C, Herrero A, Sanz M. Association between periodontal status and pre-term and/or low-birth weight in Spain: clinical and microbiological parameters. J Periodontal Res 2013;48:443-51.

17. Fogacci MF, Cardoso EOC, Barbirato DDS, de Carvalho DP, Sansone C. No association between periodontitis and preterm low birth weight: a case-control study. Arch Gynecol Obstet 2018;297:71-6.

18. Mesa F, Pozo E, O’Valle F, Puertas A, Magan-Fernandez A, Rosel E, et al. Relationship between periodontal parameters and plasma cytokine profiles in pregnant woman with preterm birth or low birth weight. Clin Oral Investig 2016;20:669-74.

19. Corbella S, Taschieri S, Francetti L, De Siena F, Del Fabbro M. Periodontal disease as a risk factor for adverse pregnancy outcomes: a systematic review and meta-analysis of case-control studies. Odontology 2012;100:232-40.

20. Xiong X, Buekens P, Fraser WD, Beck J, Offenbacher S. Periodontal disease and adverse pregnancy outcomes: a systematic review. BJOG 2006;113:135-43.

21. Macones GA, Parry S, Nelson DB, Strauss JF, Ludmir J, Cohen AW, et al. Treatment of localized periodontal disease in pregnancy does not reduce the occurrence of preterm birth: results from the Periodontal Infections and Prematurity Study (PIPS). Am J Obstet Gynecol 2010;202:147.e1-8.

22. Xiong X, Buekens P, Goldenberg RL, Offenbacher S, Qian X. Optimal timing of periodontal disease treatment for prevention of adverse pregnancy outcomes: before or during pregnancy? Am J Obstet Gynecol 2011;205:111.e1-6.

23. Polyzos NP, Polyzos IP, Mauri D, Tzioras S, Tsappi M, Cortinovis I, et al. Effect of periodontal disease treatment during pregnancy on preterm birth incidence: a metaanalysis of randomized trials. Am J Obstet Gynecol 2009;200:225-32.

24. Armitage GC . Development of a classification system for periodontal diseases and conditions. Ann Periodontol 1999;4: $1-6$.

25. Caton JG, Armitage G, Berglundh T, Chaleppe ILC, Jepsen S, Kornman KS, et al. A new classification scheme for periodontal and peri-implant diseases and conditions - introduction and key changes from the 1999 classification. J Clin Periodontol 2018;45 Suppl 20:S1-8.

Bu makalenin kullanım izni Creative Commons Attribution-NoCommercial-NoDerivs 3.0 Unported (CC BY-NC-ND3.0) lisansı aracılı̆̆ıyla bedelsiz sunulmaktadır. / This work is licensed under the Creative Commons Attribution-NonCommercial-NoDerivs 3.0 Unported (CC BY-NC-ND3.0) License. To view a copy of this license, visit http://creativecommons.org/licenses/by-nc-nd/3.0/ or send a letter to Creative Commons, PO Box 1866 , Mountain View, CA 94042, USA. 